\title{
THE EFFECTS OF CORTISONE AND ACTH UPON THE EYE SYMPTOMS IN LEPROSY
}

\author{
EINOSUKE SHIONUMA, MASAO ARAI AND NOBUKO ITO
}

(National Leprosarium, Nagashima Aiseien)

1) In 65 patients (74 eyes) of leprous eye disturbances, the local treatment of cortisone produces the most remarkable effect upon acute iridocyclitis, upper scleritis due to erythema nodosum leprosum and scleritis.

2) It is ineffective upon leprous keratitis.

3) ACTH was applied and presented favorable results on 3 patients (5 eyes) of iridocyclitis and scleritis caused by erythema nodosum leprosum in which cortisone had produced no effect.

4) The excellent efficacy of ACTH and cortisone upon erythema nodosum leprosum and accompanying acute iridocyclitis supports Mitsuda's assumption that the etiology of erythema nodosum leprosum should be considered an allergic inflammation.

\section{癩に於けろ眼疾患のコーチデン ACTH の効果}

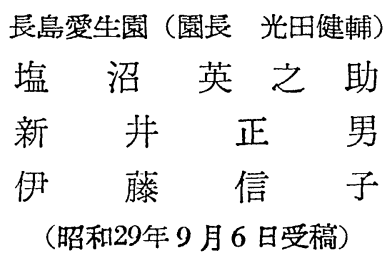

\section{1 楮㛭}

眼科領域に於て副腎皮質ホルモンの一つである Cortisoneは眼疾の急性炎衝症状或はアレルギー性炎症に卓就 を有するととは既に周知のととである。

瀨眼に於ては従来其の治療法の甚だ困難なりとせられ ていた急性虹彩毛椂体炎に対し本剤を用いるととの甚だ 可なることを報告したものには外国では Erickcon(1)， Lowe, J. (2)(3), Koff, R.(4), Dharmendra(5) 氏等があり我 国では須田, 田上, 吉永, 熊丸の諸氏 ${ }^{(6)(7)}$, 横田, 松田 画氏 ${ }^{(8)}(9)$, 塩沼, 新井, 伊藤諸氏 ${ }^{(10)}$, 中山氏 ${ }^{(1)}$ の報告 がある゚

又 ACTH は脳下垂体ホルモンであるが，其の作用は 副腎皮質を刺戟して Cortisone 其他を分泌せしめるとい われるが，眼顧に対して Cortisone 同様の効果まりとす る報告は外国では Lowe, J., (2) Marcel, M. 其他協力者(12)， Dharmendra(5) 諸氏の報告がめる。我国に於ての報告は 㙁沼, 新井, 伊藤 ${ }^{(10)}$, 中山(11) 氏まるのみでまる。余等
の如く多数例に就て取扱い単儿虹彩毛様体炎，上望膜炎 のみならず同じ瀨眼に於て瀨性角膜炎, 絖発緑内障, 宫 眼性角膜潰痓等の症例をも含めて報告したものは稀でせ る。余等は第26回日本瀨学会総会に於て報告した処を始 には詳論し, 又最近消炎鎮痛の良好なる薬凨としての Jrgapyrin と Cortisone の䠭眼えの忍用に就ての優劣に就 ても論及し参考の資とし度い。

\section{2. 治 療 方 法}

薬液はメルク会社の筋肉内注射用のコルトン・アセテ 一トの原液 $25 \mathrm{mg} / \mathrm{lcc}$ か又は生理的食塩水にて 5 倍に稀 粎した $5 \mathrm{mg} / \mathrm{lcc}$ 液を使用した。軟摘は点眼用としての $5 \mathrm{mg} / 1 \mathrm{~g}$ 濃度のものを用いた。点眼用には原液か 5 倍稀 粎のものかを用いたが主として後者を多く使用した。文 点眼を要すべきものは患者居住の寮より診祭案を訪れる ととの頻回を要する不便さを考え大体は入窒せしめるこ ととし看護婦に命じて 1 日 5 回 2 時間置き点眼とした。 中に症状の劇しいものは其の点眼 1 時間置きにしたもの 
もある。但し夜間の睡眠時間内には用いなかつた。その 症状の軽快するにつれて点眼の間隔を延ばし点眼回数を 過宜淢した。軟高の点眼は1日 1〜2 回使用した。眼注 は結膜下注射で其の原液を $0.2 〜 0.3 \mathrm{cc}$ 用いたものが多 かつたが後には倍稀釈液を用いてもさして効力には差が ないととを知り，との方が経済的でもあるので現在では 専らこの方法を用いる。全身的使用として筋肉内注射を 選んだ場合もあるが少ない。此の場合は 1 日 200mg〜 $100 \mathrm{mg}$ 使用した。併用の場合は点眼と軟寒とが多かつ た。知果判定には有効, 無効にわけ更に有効を著効と良 効に，無効を不変と患化とにわけだ。

\section{3. 治 療 成 績}

治療症例は第 1 表の如く 65 例 74 眼でその殆んどが瀨 の前眼部疾患である。最も多き疾患は急性虹彩毛梯体炎
の 34 例 38 眼，次は鞤膜炎の 9 例 9 眼，上鞏膜炎 6 例 8 眼等で瀨性角膜奏筫炎には 3 例 5 眼, 瀨性点状角膜炎心 は 1 例 2 眼，乘眼性危膜瀢湟には 5 例 5 眼等でまる。総 症例 65 例儿対し瀨性結節性紬斑（E. N. L.）を併有する ものは19例 (29.2\%) であつた。

治療期間は最短 3 日間最良 45 日であつて丑圴日数は 9.2 日である。有効率は第 1 表に見る如く灀性急性虹彩 毛様体炎には78.9\%のの有効率を示し，上䖯膜の䞄性結節 性紅斑には 100\%，上釬膜炎 100\%，墔膜炎77.7\%，絖 発線队障 $100 \%$ ，萎縮眼痛 $100 \%$ ，乘眼性角膜潰湯 $4.0 \%$ の有效率でせる。

瀨性角膜実翼炎及点状角膜炎は何れち不变で岁る。但 乙無効の者の思化例は 1 例当認め得なかつた。

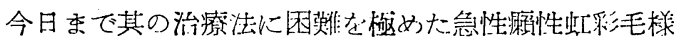

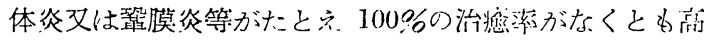

第 1 表 瀨眼に対する Cortisone の治潦效果

\begin{tabular}{|c|c|c|c|c|c|c|c|c|c|c|c|c|c|}
\hline 左串 & 籹 & 樶 & & . & 使 & 用 & 法 & & 有 & 効 & 無 & 効 & 有效率 \\
\hline 㤇 忠 名 & 列 & $3 x$ & 例 数 & 点眼 & 軟霄 & |眼注 $\mid$ & |筋注| & 併用 & 著効 & 良効 & 不变 & 誌化 & $\%$ \\
\hline 虹彩毛梯体炎 & 34 & 38 & 13 & 23 & 7 & 3 & 2 & 3 & 18 & 12 & 8 & 0 & 78.9 \\
\hline J鞤膜 E.N.L. & 2 & 2 & 2 & & & & & & 2 & 0) & 0 & ${ }^{\circ} 0$ & 100.0 \\
\hline 琴 膜 炎 & 9 & 9 & 1 & 3 & 4 & 2 & & & 4 & 3 & 2 & 0 & 77.7 \\
\hline 菊萄 膜 炎 & 3 & 3 & & 1 & & 2 & & & 0 & 1 & 2 & 0 & 33.3 \\
\hline 䋩発緑内障 & 1 & 1 & & 1 & & & & & 0 & 1 & 0 & 0 & 100.0 \\
\hline 萎 縮 眼 痛 & 1 & 1 & 1 & 1 & & & & & 1 & 0 & 0 & 0 & 100.0 \\
\hline 香眼性角膜潰演 & 5 & 5 & & 3 & 2 & & & & 0 & 2 & 3 & 0 & 40.0 \\
\hline 角膜実湼炎 & 3 & 5 & & 5 & & & & & 0 & 0 & 5 & 0 & 0 \\
\hline 点状角膜炎 & 1 & 2 & & 2 & & & & & 0 & 0 & 2 & 0 & 0 \\
\hline 計 & 65 & 74 & 16 & 47 & 14 & 8 & 2 & 3 & 28 & 24 & 22 & 0) & 70.2 \\
\hline
\end{tabular}

率にその有効率を見るととは従来の治療法の捗かばかし く行かなかつた事と比較し甚だ警是的で多る。

又此等局所療法のらち点眼療法も結膜卜注射療法も阔 様な効果を認めるのであるが，软亶の場合には余等の㬰 験で梳爾他療法に比較すると其の効果性分劣るよらで おる。

又此の療法によつてしてb急性の虹彩毛様体炎文は琗

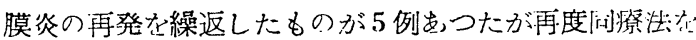

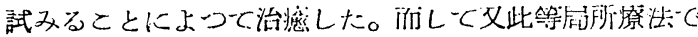

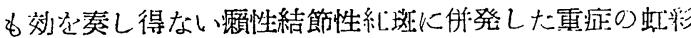

毛様体炎があるのであつて（即ち本例は約 1 週間点眼療 法を試みたにも拘らず無効でむつた例。）かかる应例に 1 日 $200 \mathrm{mg} \sim 100 \mathrm{mg}$ のコーチゾンの筋注を試みたのに 2 日間程で卓効を奏した。

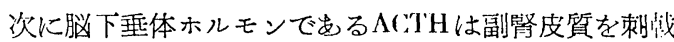
してコーチゾン其他を分泌せしめるのであるが Marcel， M. 及その協力者 ${ }^{(12)}$ は結節瀨の癩反忍 6 例にとれを試み

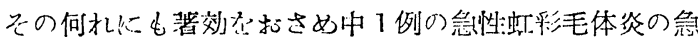

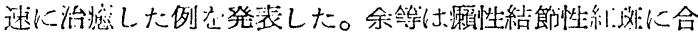
䏳した重症の急性虹彩毛体炎，及浑膜炎で局所コーテン゙ 
第 2 表 瀨性結節性紅斑に合併せる重症眼疾患の AC'THI の治療効果

\begin{tabular}{|c|c|c|c|c|c|c|c|c|}
\hline 疾 患 名 & 痽: 例 & 左右眼別 & 1 日量 & 治療期間 & 注射全量 & 眼の効果 & $\begin{array}{l}\text { E.N.L. } \\
\text { に対す } \\
\text { る効果 }\end{array}$ & A GTH 治療前の療法 \\
\hline \multirow{2}{*}{$\begin{array}{l}\text { 虹夥毛様 } \\
\text { 体炎 }\end{array}$} & 三，弘， & 左, 右, & $60 \mathrm{mg}$ & 8 日 & $480 \mathrm{mg}$ & 著 效 & 有 効 & $\begin{array}{l}\text { ストマイ，ダンケルン， } \\
\text { スチブナール,コーチゾン点眼 }\end{array}$ \\
\hline & H, 一, & 左, 右, & $30 \sim 80$ & 7 日 & $360 \mathrm{mg}$ & 著 効 & 有 効 & 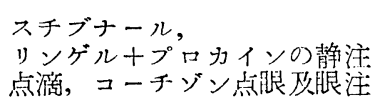 \\
\hline 墇 膜 炎 & 向, は， & 右 & $\begin{aligned} \mathrm{mg} \\
40 \sim 80\end{aligned}$ & 7 日 & $360 \mathrm{mg}$ & 著 効 & 有 効 & $\begin{array}{l}\text { スチブナール, } \\
\text { コーチゾン点眼 }\end{array}$ \\
\hline
\end{tabular}

ン㙩法にも抗しその他㙩法で難治だつた結節癩 3 例 5 眼 に「アーマ」研究所の $\Lambda$ CTH の筋注を試みた。1 回の使 用量は $20 . \mathrm{ng} \sim 10 \mathrm{mg}$ として 6 時間間隔に筋注した。症例 に就て述べると，三，弘の例は治療期間 8 日で注射全量 $480 \mathrm{mg}$, 山, 一の例は 7 日間で注射全量 $360 \mathrm{mg}$, 向, は の例は 7 日間で注射全量 $360 \mathrm{mg}$ でもつた。

その瀨性結節性紅斑ならびに合併せる眼疾に対する効 果は第 2 表の如くでその何れに対しても麦効しだ。此の 場合本症例 3 例に何孔子存在した濑性角膜実質炎は治傯 しなかつた。

たゲューチゾンの如き薬羭は全身療法としててれを筋 注用とし常時頻頻使用するには余りにも高価楽たること を恨みとする。

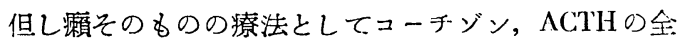
身的投与法によるととの無効でするととは既に Lowe, J. 行奧, 安西両氏 ${ }^{(13)}$ 其の他も指摘している処である。文コ 一チゾンの局所療法として横田, 松田両氏は䟥性的膜炎 にも有効としたが余等は瀨性点状角膜炎, 瀨性角膜炎の 4 例 7 眼の症例に対し 1 日 5 回の点眼で最短 41 日より最 長45日間観察したがその効果は認められなかつた。即ち コーチン゙ン使用は原因療法ではないのであるから噼の全 身療法即ちプロミン，D.D.S.等の投与を常に併用すべき ものと考える。

泰西でいら瀨反心即ち我が国でいら瀨性結節性紅班， 並びにそれに附随する急性の関節炎, 神経炎, 急性虹彩 毛様体炎等化対し，有効なるととはLowe, J., Erickson, Marcel, M. 及其の協同研究者等ならびに我々も亦とれを 是認するすのでする。だだ中山氏(11) によれば全身投与 は局所投与法に劣ると述べた。

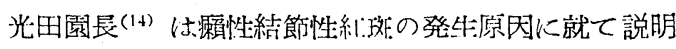

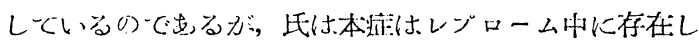
た瀨菌が治療によつて破坮し，その退行性産物中に含ま
れたシベルクリン様物質が抗原となり，既に血清中に存 在する抗体との間に起る抗原抗体反応に帰すべしとして いる。即ち本症を一つのアレルギー性炎とみなしている のでめる。されば我々は此等の薬凨が急性乃至亚急性 炎症たる本症ならびにその随伴症状として特に重要なる 急性虹彩毛㥞体炎等に卓効を呈する所以が肯定出来るの である。而して局所的に用いたコーチゾンが局所应状の 炎泟を扣さえきれなかうた例があるのは，恐らくその局 所使用のみによつて其の增覀炎症が鎮压されるには余り にる全身状態がよくなかつたと考えられる訳である。

最近 Irgapyrin が良好なる鎮痛沜として登場した。こ れに就ては塩沼 ${ }^{(10)}$ 其の他も既に第 2 回西部㸊学会に於 て難波氏 ${ }^{(15)}$ の演題に追加したように癞性神経痛や急性

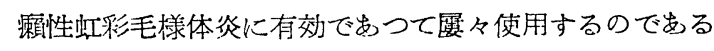
が，本㓮はピラッオロン誘導体ブタン゙リジンとアミノピ リンの等量よりなる消炎, 鎮痛の薬剤である。結節瀨に 使用する場合時に本剤の副作用として筋注㨁後每回瀨性 結節性紬班を誘発する者のあるととである。このととは 本年熊丸, 羽地(17) 氏等も指摘する処で発等等が起り再 び患者を眼疾のみならず全身的に苦しめ甚だ不愉快な現 象である。かかる場合此のコーチン゙ンの結膜下注射乃全 点眼は決して副作用なく安心して用いられるととを追加 するものである。

\section{4. 結論}

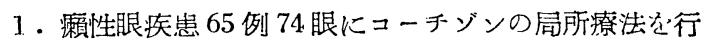

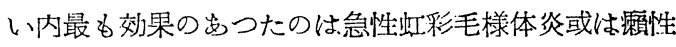
結節性紬理による上鞤膜炎，珜膜炎等で岕る。しかし 鬼眼性角膜潰堭には有効，無効半ばしていた。

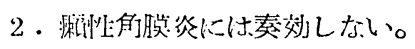

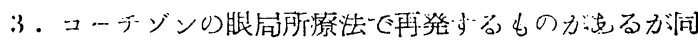
潦法艾繰返すととにより軽快する。 
4. 瀨性結節性糺斑に於て重篤なる虹彩毛様体炎, 鞤膜 炎を起した 3 例 5 眼のコーチゾン其の他の療法で難治 だつたものに対し AC'TH の全身療法を試みた。これ は癩性結節性紅玟並びに急性虹彩毛㥞体炎, 鞤膜炎に 対し何れも有効でめつた。

5 . 䅋性結節性紅斑並びにこれに伴う急性虹彩毛样体炎 等に ACTH，コーチゾンの奏効するととは光田氏が瀨 性結節性紅斑の発生原因をアレルギー性炎と見做して いるととを裏書きするものでむる。

6. 急性瀨性紅彩毛样体炎の治療薬としてコーチゾン及 Irgapyrin の副作用如何を比較すると Irgapyrin は往々 瀨性結節性紅斑を誘発するととがある故に，むしろ副 作用のないコーチン゙ンの局所療法を選ぶ方が無難でめ る。

擱筆に当り御校閲を賜つた光田園层に哚梘なる謝意と 裴す。

\section{文献}

1) Paul T. Erickson: The Treatment of Leprosy. Annals of the New York Academy of Sciences. Vol. 54. Art. 1 Leprosy. 1951.

2) Lowe, J.: British Med. J. 1 (1952) 601

(Correspondence) Abstract from Int. J. Lep, 1952, $20: 405$.

3) Lowe, J. : British Med. J. 1 (1952) 746 749.
Abstract from Int. J. Lep, 1953, $21: 121$.

4) Koff, R.: Int. J. Lep, 1952, $20: 257$.

5) Dharmendra: Leprosy in India, 1953, 25:123 140.

6）須田,田上,吉永, 熊炕：治療,第 34 卷 12 㫔 1111 頁, 昭和 27 年.

7）吉永，熊丸：第 7 回医務局研究発表会報告集，昭 和 27 年.

8）横田，松田：日本瀨学会第 2 回東部地方会レブラ 第 21 巻 210 頁, 昭和 27 年.

9）横田, 松田：第 7 回医務局研究発表会報告集, 吉 永, 熊丸画氏演題の追加, 昭和 27 年.

10）塩沼，新讲，伊藤：レプラ第 22 巻第 4 号 217 頁, 昭和 28 年.

11）中山：第 23 回九州眼集，眼臨，48 巻 2 号 131 真 昭和 29 年.

12) Marcel, M., Convit, J., Medina, J. A. and Blomenfeld, E. : Jnt. J. Lep, 1951, 19: 137 145.

13）谷奥，安西：医人，1953，第 1 号.

14) 光田：医療，第 7 巻 5 号 327 頁.

15）難波：第 2 回日本瀨学会西部地方会レプラ第 22 巻 第 6 号, 332頁.

16）塩沼：同上演説の追加，レプラ第 22 巻 332 頁.

17）熊丸，楳木，春日，羽地，日高：第27回日本瀨学 会発表, 昭和 29 年. 